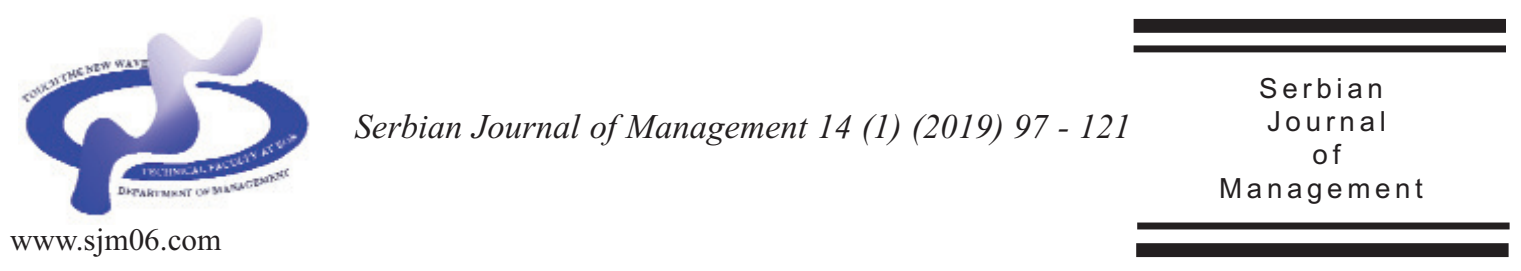

\title{
EMPLOYEE VOICE: SPEAKING UP IN ORGANISATION AS A CORRELATE OF EMPLOYEE PRODUCTIVITY IN OIL AND GAS INDUSTRY - AN EMPIRICAL INVESTIGATION FROM NIGERIA
}

\author{
Olusegun Emmanuel Akinwale* \\ Department of Business Administration, Faculty of Management Sciences, \\ University of Lagos, Lagos, Nigeria
}

(Received 10 October 2017; accepted 8 October 2018)

\begin{abstract}
The understanding and interpretation of voice have been given critical attention among researchers, practitioners in recent years. The firm believes of the workforce that they can openly express their personal opinion and concerns to higher authority in the organisation, and who believe that they can influence the decision, are likely to demonstrate optimistic attitude and constructive behaviours. The study surveyed 1067 employees of Nigerian oil and gas and 902 respondents were returned and used for the study. Data were obtained from the participants using a questionnaire of 19 question items by means of probability sampling strategy, while the research design was crosssectional. The findings of the study indicate a coherent and consistent one with literature. The study employed eight dimensions as drivers of employee voice in the Nigeria oil and gas industry which discovered mixed outcomes. One of the drivers is the communication/exchange of views which had an inverse association with employee productivity. Employee collective representation and employee engagement also recorded an insignificant relationship with employee productive work behaviour. However, employee participation, improved management systems, employee supervisorsubordinate relationship, workforce contribution and upward problem solving were significantly correlated with employee productive work behaviour. The study used descriptive statistics and Pearson moment correlation in analysing the data gathered from the participants and concluded that workforce of Nigerian oil and gas are not deeply engaged with the workplace environment due to the observed challenge of not allowing them to be duly represented and discourage them from exchanging their views and ideas.
\end{abstract}

Keywords: employee voice, employee participation, improved management systems, employee supervisor-subordinate relationship, two-way communication, employee productivity

\footnotetext{
* Corresponding author: akinwaleolusegun@yahoo.com
}

DOI: $10.5937 /$ sjm14-15308

ORCID: orcid.org/0000-0001-5835-9698 


\section{INTRODUCTION}

In all organisations in the world, employee voice and productivity has notably become a contentious discourse as well as in the literature. Creating a productive employee is instrumental in achieving organisational goals and objectives. This is more reason why high-performance culture in corporate firms emanates from satisfied and productive personnel work behaviour. Employee exhibiting increased productive work behaviour in the workplace is a function of diverse factors in which motivation is the core of it. Creating a good work environment to improve and advance his/her career is another driver of a productive employee at work. Above all, employee participation and ensuring employee voice is recognised and heard in the firm is key to enhancing employee productive work behaviour. However, encouraging employees to express themselves on what they are going through in the course of their job task assist them in shaping organisational performance and employee productivity in the work environment.

However, the concept of employee voice in relations to employee productivity has attracted much attention in recent times, especially between management of organisations and trade unions. Employee voice comprises of all kinds of opportunities where an individual employee will have a chance to express himself and exert some influence on workplace decisions (Boxal \& Purcell, 2011). Employee voice is described as championing and speaking up on certain fundamental issues bothering employee productive work behaviour (Morrison, 2011). In a more apt explanation, Purcell (2014), presents another dimension of employee voice as demonstration of individual employee displeasure among managers and subordinates or through grievance procedure; secondly, demonstration of collective employee displeasure raised by trade unions through collective bargaining action; thirdly, contribution to management decisionmaking process through a two-way communication, problem solving, suggestion systems and attitude evaluations; and lastly, through shared partnership understanding, joint consultative forum and work councils (Anyago et al., 2015).

Fostering and inspiring employees' ability to communicate their intentions and feelings to the management of an organisation elicit enhanced employee performance and change, stimulate learning, superior individual and group performance (Morrison, 2011). It is glaring that at any point in time when employees intentionally provide suggestions, concerns, information regarding issues or work-related opinions to someone in higher position of the corporate organisation, they engage in upward voice mechanism, however, when they cease such meaningful contributions, they rather showing silence and depriving their organisation of potentially useful information (Burris, 2012).

However, extant literature has demonstrated qualities of employee voice to both firms and employees, benefits of employees' voice, inputs to foster firm's effectiveness and competitiveness (Budd et al., 2010; Kim et al., 2010; Hussein et al., 2013; Umar \& Hassan, 2013; Okpu \& Jaja, 2014; Zhang \& Xiuyuan, 2014). Allowing employees to have a greater influence on the conduct and operations of their job task, encouraging their contributions are seen to be significant and worthwhile for firms and 
employees (Kim et al., 2010). Hence, employee voice is an imperative means of motivation which assists organisational workforce in improving their productivity and feel more satisfied (Dwomoh, 2012).

Worthy of recognition, once an effective voice of employees is reckoned with, employees' opinions are sought for and listened to, aside from discovering that their views are taken into consideration and make a difference, it also enables employees to feel a high sense of ownership and deeply connect to the work environment (Macleod \& Clarke, 2009). Appropriately, corporate organisations have to depend on the collective efforts of their employees and listen to their input and ensure that it is an essential piece in resolving issues and problems and establishing substitutes (Yin, 2013).

In spite of advantages and benefits of practising employee voice and the need to encourage it, it seems it is not the current situation in many organisations in Nigeria workplace. It has been observed that degree of employee satisfaction which influences their productivity level in some organisations largely reduce as employees are not given such opportunity to express and communicate their inputs and opinions on issues related to their organisations, and this is much tolerated in some firms in oil and gas in Nigeria. Employees who are encountering job associated challenges decide to reluctantly accept their organisation management judgement or remain silent and this becomes a case of if you cannot beat them you rather join them. Moreover, the fear of losing their jobs or endanger their jobs once they choose to communicate their opinions and feelings make some of them remain silent and also the no-job syndrome makes many of Nigeria employees to support management in the face of detrimental attitudes to their productivity.

It has been observed recently that once employees communicate on seemingly bad ideas or attitude of managers or management such employees are tagged anti-management and they tend to frustrate such individuals' efforts. There is a whole of issues surrounding employee welfare, safety on the job, work-life balance, compensation and remuneration amongst others in Nigeria workplace. Should anyone decide to communicate with this management of such organisation will discreetly show such individual exit way out of the company. These and much more are the issues bordering around employee productive work behaviour in Nigeria which need an intervention and decisive way of ameliorating such in Nigeria. It is base on this, that this study wanted to evaluate how voice employees are in Nigerian oil and gas industry workplace. Thus, the study aims to evaluate the significance of drivers and components of employee voice on the totality of productive work behaviour of Nigerian workforce in oil and gas industry and seeks to look at the following objectives:

i. The relationship between communication/exchange of views and employee productivity

ii. The significance of employee collective representation on employee productivity

iii. The essence of employee engagement on employee productivity

iv. The relationship between upward problem solving and employee productivity

v. The correlation between employee participation and employee productivity

vi. The importance of employee contribution on employee productivity

vii. The impact of improved management 
systems on employee productivity

viii. The connection between employee Supervisor-subordinate relationship and employee productivity.

\subsection{Delimitation of the Study}

This paper focuses on evaluating significance of employee voice on employee productivity in Nigeria oil and gas industry. The choice of oil and gas is made due to the essential nature of oil and gas to Nigeria economy, it is one of the most viable industries in the economy, responsible for over 70 percent of Nigeria's revenue from exported products. In the past four decades, the industry has been of strategic importance to the country's economy as it accounts for about $90 \%$ of the country's total earnings from foreign exchange (Oyejide \& Adewuyi, 2011). Organisations included in the sample were taken from oil firms in Lagos and Port Hacourt. The two geographic locations are major commercial business hub especially for oil and gas in Nigeria with concentration of firms in Lagos and Porthacourt (Beulah \& Obot, 2013), and well over 75 percent of the oil and gas firm in Nigeria have their head offices situated in Lagos State (Nwanyanwu et al., 2015). Hence, Lagos and Porthacourt provide a justification for the study.

\section{LITERATURE REVIEW AND THEORETICAL FRAMEWORK}

The concept of employee voice has been clearly demonstrated in the literature that employees who firmly hold the belief that they can openly and freely communicate their personal intentions and concerns to management of the organisation, and who believe that they can contribute in the decision-making process, are likely to exhibit optimistic attitudes and will definitely exhibit constructive work behaviours (Holland et al., 2011; Rees et al., 2013). Employee voice has provoked positive outcome to organisations across the cultures and economic zones of the world (Morrison et al., 2011). Farndale, Van Ruiten, Kelliher, and Hope-Hailey (2011) in support of this assertion, arguing that employee voice affords workers chance to willingly express their minds, and engenders the belief that their contributions are noteworthy, it accords a high degree of respect towards the management of corporate firms, hence, there is a close link between employee voice, productivity, organisational performance, and development of employee trust in senior management.

\subsection{Underpinning Theories}

\subsubsection{Exit-Voice-Loyalty Theory}

Exit voice theory is also a significant theory when one is evaluating the concept of employee voice in relation to employee productivity. The theory was initiated by Hirschman (1970). The theory is in place in order to explain the connection between union voice, higher productivity and lower rate to quit the organisation. The theory stipulates that there are two types of response to unsatisfactory situations in an organisation. The first is an exit or leaving without trying to fix things. While the second is a voice which means speaking up, able to express and communicate to curb the shortcomings of the management. Loyalty can modify the response, enabling an individual employee to stand tall and fight (voice) for what seems right rather than run 
away from reality (exit). While Hirschman (1970) explained voice in his theory as an attempt to modify instead of running away from an unsatisfactory socio-economic relationship in work setting or the national life of individuals.

In the organisational behaviour dimension, employee voice is a device in which employee work within the system, using direct communication to bring about internal change that yields desired situations, and exit is the device that employee employed in pursuing their interest elsewhere by quitting a less desirable job for more desirable jobs. Freeman, Boxall, and Haynes (2007) claimed that if employees' voice will be effective and reverberating in delivering of their agitations and affect management's attitudes and behaviour towards employees, it must be a collective voice, unison and one voice. Without one voice in which the union worker representation, employees lack the incentive to pursue public goods, such as enhanced working conditions and workplace policies and procedures that will impact favourably on the well-being of all employees such as grievance and arbitration procedures, just cause for discipline and discharge, seniority clauses (Batt et al., 2002). In another dimension, the Hirschman (1970) theory shows the presence of exit option can largely reduce the possibility that voice will be heard and so Hirschman introduced the dimension of loyalty. Loyalty indicates a feeling of dedication and attachment to a firm in which an individual is a member. The presence of loyalty effectively heightened the cost of exit. Therefore, it affords workers to glue with the undesirable firm for a while, thereby decreasing excess exists. Being loyal to a firm shows an individual believes about the organisation over a period of time, which prescribes that the right turns will be more than balance the wrong ones. Given that exit is kept at bay, employees are more likely to assert their voice mechanism. While the firm could not also afford to neglect the rebellion voices for too long as it is detrimental for such a firm.

The relevance of this theory to this paper is that employee voice is seen in the participative notion of the theory that is, the theory demonstrates how neglect of voice which is silence and quit or exit for a better work environment will allow the employee to succeed in terms of achieving their career goals and meeting their needs. It is synonymous with this study as employee participative and involvement, communication/exchange of views, collective representation, improved management systems are part of what this study seeks to analyse.

\subsubsection{Active/Passive and Constructive- Destructive Theory}

The active-passive and constructivedestructive theory are pioneered by Gorden (1988) which conceptualised that there are two major and noteworthy frameworks that seek to prescribe and forecast employee voice in the workplace. The first is on the two continuum active-passive and the second is also on the two spectra of constructive and destructive structure. The theory stipulates that there are four quadrants in which employee voice can be heard. Activeconstructive is characterised by making suggestions, union bargaining and principled discord or disagreement, it is also ordered by the robust and strong currency of force and power. Passive constructive is initiated by the reduced intensity and this involves attentive listening, quiet non-verbal support, 
- Antagonistic Exist

- Bad Mouthing

- Verbal Aggression

- Duplicity

- Ingratiation

- Complaining to Co-workers

\section{Active}

Destructive

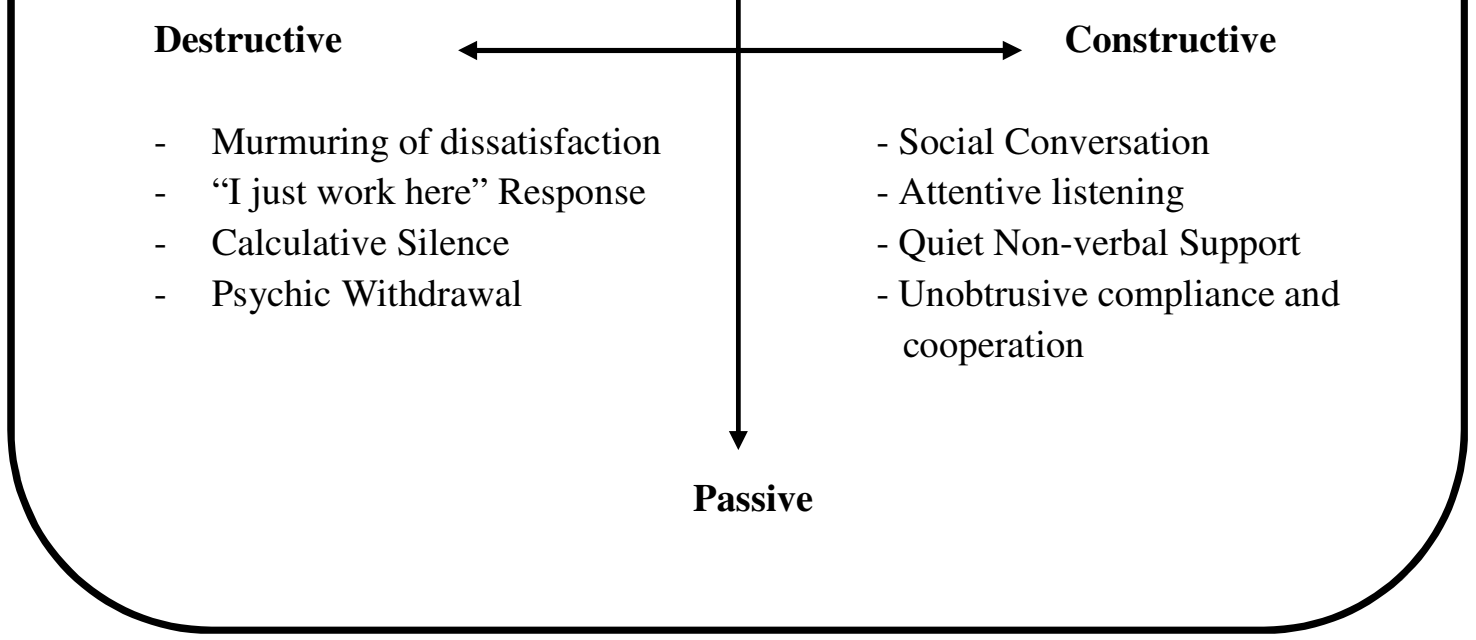

- Murmuring of dissatisfaction

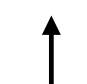

- "I just work here" Response

- Social Conversation

- Calculative Silence

- Psychic Withdrawal

- Principled Dissent

- Co-determination

- Protest

- Participative decision making

- Bolsterism

- Argument/Dialectic

Figure 1. Gordon Active-Passive and Constructive-Destructive Theoryl

and unobtrusive cooperation. While active destructive is also planned by increasing intensity and consists of verbal complaining to fellow employees, verbal aggression and antagonistic exist. Passive destructive, like passive constructive, is arranged by reducing the intensity and entails complaining and grumbling, apathy, silence and withdrawal. In furtherance of this theory, there have been several publications that seek to explain why employee voice is crucial to organisations. Specifically, two certain theories have come up in one that combines Gorden's (1988) theory of active-passive and constructivedestructive. The first theory entails moralethical dimension while the second theory is more centred on a political view.
The first theorist who discussed a moral need for employee vocal expression was Gorden (1988) who argued that communication is crucial and fundamental social device. Expression of voice is rooted in human survival. Gorden (1988) posits that there is a universal need for an individual to express himself. After two decades, Van Buren and Greenwood (2008) take a similar position with Gorden's theory and stretched further the moral right argument. Van Buren and Greenwood (2008) emphasize on the loss of employee voice on the employer as business ethics issue on the basis that a structured and planned society consists of social institutions within which human beings will nurture and develop their moral 
ability and fully become cooperating individuals in a society of free and equal citizens. In furtherance of this, Van Buren and Greenwood (2008) argue that management in corporate firms is obligated to the moral right of workers concerning voice opinions and participate in decisionmaking in return for worker's job functions. From a political dimension, Gorden (1988) was of the opinion that human voice falls under basic rights category. He referenced John Locke's assumption that an individual owns his labour and states that an employee denied of expressing and communicating their dissatisfaction and opinions concerning the decisions that affect the lives of employees' labour is a breach of this basic human contract.

Gorden (1988) states that an organisation should first transform itself from space to place shifting into an environment where its workforce is connected with the management, related by a commonplace, a common language, and common experience. Once an open and objective environment has been maintained, it is imperative to further establish an open organisation that stimulates dialogue and two-way communication. The theory of Gorden hypothesizes that firms should encourage individual voice, make visible efforts to appoint worker voice platforms, create group speak-up session with supervisors, provision of question and response columns with administrators in organisation newsletters, and offer allow other forms of communication to increase from down or bottom to the top. In his theory, Gorden (1988) suggests that employers give their employees stock and ownership plans to stimulate and promote genuine feelings of commitment to the organisation.

However, this theory is relevant to the study of employee voice and their productivity in the Nigerian oil and gas industry. It appropriately connects to the theme of this study. The theory gives credence to the behavioural clues of both management and employees and give them understanding that workers' active constructive behaviour is denoted as voice whereby they want improvement over the actions of management of the organisations, they will be actively seeking to normalise and improve the conditions by suggesting ways of enhancing seemingly observed bad situations, discussing with management, joining the union and related behaviours. At the same time, it lends credence and teaches the employees to be dedicated to their organisations by passively and constructively engage in the affairs of the firms in which the workers optimistically have the belief for the improved situation to turn around and trust the management of Oil and gas firms in Nigeria. While it will give the management of firms understanding and open their horizon that passive-destructive behaviour of her workers will amount to neglect when they are allowing conditions to worsen and this behaviour is usually tied with being late and absent from work, social loafing, dysfunctional work behaviour, reduce their efforts and increase errors at work.

\subsubsection{Social Capital Theory}

The social capital theory has its root in Bourdieu (1980) and is relevant and applicable to social environment and exchange relations in modern days. Bourdieu's work attempts to demonstrate how social capital is employed to basically produce or reproduce inequality, showing for instance how people gain access to powerful 
positions through the direct and indirect employment of social relationships. The theory stipulates that the quality of the relationship between employee and management influences the firm's effectiveness by affecting the processes quality entrenched within the organisation (Lin, 2001; Seibert et al., 2001). Therefore, the theory argues that good quality relationship between employees and supervisor not only benefitting the individuals involved, but also benefit the organisation as a whole because when a critical mass of social relationships between the corporate organisational hierarchy is effective, it means that information, resources, emotional support, trust and goodwill are flowing bi-directionally and social capital within the organisation is accruing (Kessels \& Poell, 2004). Giving this background, employees may be better armed to undertake roles, solve problems and meet the needs of the client efficiently and effectively, which was one of the stated objectives of implementing corporate organisation as reforms (Ferragina, 2010).

The social capital theory has multiple meanings, interpretations and uses, the emphasis of social capital is on certain benefits and rewards given to the parties involved, it flows from trust, reciprocity, information and cooperation connected with social interactions. It creates value for the individual who are linked together and associated stakeholders as well. While negative norms of exchange reciprocity discourage and serve as an impediment to detrimental and violent behaviours (Chen et al., 2009).

However, the assumption and growth of social capital theory point to the fact that firms need to encourage, value and reward appropriately, interactions building between employees at several stages of the organisational hierarchy. Some studies argued that the way the corporate organisation has been employed using control measures based on inappropriate performance yardsticks (Detert \& Edmondson, 2011) and has conditioned supervisors to use formalised control parameter towards employees (Alfayad \& Arif, 2017). This approach may have a tendency to change the relationship between employees and supervisors and consequently, may lose the potential inclination of social capital assumptions. Therefore, investigating employee's satisfaction and productivity with organisational processes, especially those measuring employees' satisfaction with types of communication with supervisors, may offer some kind of insight into the quality of social capital within organisations and its impact on overall organisational effectiveness in the long run.

In furtherance of this theory relevance, social capital argues that the quality of social relationships affects the overall effectiveness of the organisation. However, this theory vividly resonates this paper as it speaks to the objective of the paper on the superiorsubordinate relationship. It connects to the supervisor-employee relationship in the study area, how the social exchange interactions influence employee productivity and organisational effectiveness at large. In this study, the social capital theory framework is employed to explore communication relationship between employees and their supervisors, influence company performance as a means of determining the impact of corporate management on the development of social capital within organisations. 


\subsection{Conceptual Review}

\subsubsection{Employee Participation and Involvement and Employee Productivity}

Employee participatory and involvement is key and significant in any organisation, most firms these days cannot jeopardise their chance to competitors. It is imperative for all managers of corporate firms to actively and deeply involve her employees in the decision-making process, by so doing it enhances the productivity of the workers and boost the sense of belonging to the organisation. This shapes employee thought and make them take ownership position of the organisation. It is considered the process of involving all the employees of an organisation in decision-making irrespective of levels in the organisation. In support of this, Oloo and Orwar (2016) concluded that enhancing employee participation in decision-making and although organisation affairs with effective communication in which manager employs a two-way communication among the employees are essential in foster higher productive work behaviour and elicit high-performance culture in the organisation. Gilley, Gilley and McMilllan (2012) are of the view that managers should learn to be an active listener who gives an opportunity to the employees to present their views and suggestions and act on them. It is therefore pertinent that management encouragement of employees' voice will assist in increasing employees' well-being and productivity. At the same time, involving employees in the entire affairs of the organisation especially decision-making process by means of employee voice in terms of expression and free communication of their mind-sets is directly connected to higher productivity
(Griffin \& Moorhead, 2013). It is also argued that encouraging employees in sharing their opinions on a specific perspective is significantly correlated with robust employee well-being (Hambley et al., 2014).

When employees have the feeling that they are recognised and appreciated in their workplace, they have the idea that they have influence over what they do in such an organisation. Thus management presents workers with an opportunity to have autonomy and total control over their work and this stimulate their interest in giving their best effort for the accomplishment of organisation goals and objectives (Salvendy, 2012). In furtherance of the significance of employee participation and positive productive work behaviour, Creigh et al. (2012) and Bradley and Nejad (2012) claimed that employee participation is very crucial in the overall performance of firms by way of allowing employees' voice to be heard at all levels and every time. In a recent study, Beirn (2015) argued that involving employees in decisions and policies change that directly affect their job, while empowering employees to be more autonomous, greatly boosts employee morale. He further suggested that employees that are accorded better treatment like an asset and their input are considered, increases their confidence within the team members, and the firm obtains significant benefits in different shades of the organisation such as enhanced productivity, customer satisfaction and employee loyalty.

The benefits of employee participation in decision-making affecting employees wellbeing and matters concerning them in firms were aptly arranged in a study by Kuye and Sulaimon (2011). The duo posits that there is an assumption taken by some scholars and managers that the moment employees are 
suitably informed about things concerning them and are afforded the chance to make decisions important to their work, then there will be benefits for both firm and the employees. Therefore, the following are the benefits of employee involvement and participation in organisation decisionmaking as maintained by Kuye and Sulaimon (2011):

a. It enhances workers' morale and boosts their job satisfaction, improves productive efficiency.

b. It offers workers' chance to employ their private initiative and information, which can bring about the better decision for the firm (Williamson, 2008).

c. As a result of access to allow employees to freely express themselves, it improves organisational flexibility, product quality and productivity (Preuss \& Lautsch, 2002).

d. It maintains a greater sense of trust and control on employee part.

e. Through employee involvement, resources needed to coordinate and manage workers' compliance such as supervision and work rules, which can be reduced thereby decreasing costs.

f. Giving workers' opportunity to hear their views and deeply contribute their ideas and suggestions in decisions affecting the organisation, improves firm's performance and maximises perspectives of diversity.

\subsubsection{Employee Supervisor- subordinate Relationship and Employee Productivity}

Employee voice is notably recognised in work setting environment and this includes complaints that they may have regarding their working conditions, supervision between superior and employees at work, work task and other related issues bothering around work setting (Mayfield \& Mayfield, 2009). The contemporary business environment is becoming tensed and highly competitive, which makes it strenuous for a business leader in the industry to survive. Human resources and organisational behaviour are of great importance for survival and the development of any modern business. Many business executives poised that major factors contributed to low employee efficiency as to do with the reduction of their personal feelings, motivation and poor relationship between superior and subordinate at work (Chalikias et al., 2014). Cohen and Prusak (2001), maintained that one of the key substances that determine organisational effectiveness is the quality of social interactions and networks between employees and management which influence the ability to undertake tasks effectively and solve daily challenges in corporate organisations.

However, the pertinent essential ingredient that bound effective relationship together in the workplace, especially between superior and employees is effective communication. As the primary form of communication, a breakdown in the process may lead to dysfunctional work behaviour from employees which has fundamental implications for the overall performance throughout the entire organisational life (Farndale et al., 2011). Communication in a superior-subordinate relationship has been widely expressed as an exchange of information and influence among organisation members, one of whom has official authority to direct and evaluate the activities of the subordinates of the firm (Holland et al., 2011). Jablin (2009) explained superior-employee communication patterns as a kind of work relations in superior-employee relationships. 
$\mathrm{He}$ categorised the superior-subordinate communication literature into nine classifications which include interaction patterns, openness in communication, upward distortion of information, the gap in understanding between superior and subordinates, superior feedback, and the quality of effective communication against ineffective superiors.

Avery, Richeson, Hebi and Ambady (2009) and Ballone (2007) suggested that supervisor-employee interactions is best perceived and understood as a line that exists between the two, a kind of psychological platform in which all communications, reactions and feelings must go through back and forth (Campione, 2014). Through this relationship avenue, each party sees, interprets and reacts to another. The openness, the amount of freedom or genuineness of this pattern contributes to the quality or tone of the relationship, which, in turn, is the essence of the working relationship.

\subsection{Employee Productivity}

In provoking and creating an effective organisation, the workforce is the key element to bring sustainable competitive advantage to firms and without being productive and exhibiting effective work behaviour. Employee productivity has been noteworthy in both human resources management and organisational behaviour literature as well as organisational management practitioners. Rees et al., (2013) stress that employee productivity is what worker produce with the least effort. Productivity is a ratio to measure how well an organisation, individual, industry and nation concerts input resources, labour, materials and machines, into finished goods and service with improved turnaround time. There exists ever-increasing competition from the industry today and research has consistently indicated that employee perform better if they have an idea that their efforts and works are appreciated and valued at all times (Goldberg et al., 2011). This depicts that it is fundamental to keep productivity high by motivating and supporting employees to drive the firm's business in achieving set goals for the organisation. Remaining productive is not just responsibility of individual employees, but rather it is the responsibility of the management of the organisation to ensure that supportive work culture is established for the organisation in order to realise highperformance culture in the organisation among its workforce. Bornstein (2007) states that an organisation where employees are exposed to stressful working conditions, productivity is negatively influenced and that there is a negative impact on the delivery of service. On the other hand, if working conditions are better, productivity will increase and there will be a positive influence on employee work behaviour. Hence, the need to evaluate the following hypotheses become imperative in this paper:

Ho1: There is no relationship between communication/exchange of views and employee productivity.

Ho2: Employee collective representation has no significance in employee productivity.

Ho3: Employee engagement has no positive influence on employee productivity.

Ho4: Upward problem solving has no significant relationship on employee productivity. Ho5: There is no correlation between employee participation and employee productivity.

Ho6: Employee contribution in the 
workplace has no relevance to employee productivity.

Ho7: There is no relationship between improved management systems and employee productivity.

Ho8: There is no connection between employee Supervisor-subordinate relationship and employee productivity.

\section{METHODS}

This research is premised on a survey study of oil and gas firms operating in Nigeria business domain. To establish the relevance of speaking up in the organisation as a correlate of employee productivity, a cross-sectional research design was conducted in gathering data from employees of oil and gas organisations in Lagos State and Porthacourt, Nigeria. The reason was that the two geographical states are the largest concentration of Oil firms in Nigeria. While the justification for employing crosssectional is that it assists in forecasting behaviour and it tends towards correlational strategy (Sedgwick, 2014). Participants were sought from all the oil and gas organisations in Lagos and Porthacourt on a plethora issues threatening their speaking up in organisations and productivity. The questionnaire was used as the data collection instrument in order to obtain appropriate information from the respondents. According to Ohiorenoya and Uwadiae (2016) Nigeria oil and gas industry has a total staff strength of 26696 and the study has taken liberty in chosen $4 \%$ of the total population which is 1067 respondents. The choice of doing this is supported in Weisberg and Bowen (1997) who were of the opinion that $3 \%$ to $4 \%$ is the acceptable level in survey research for predicting meaningful outcome of a research and further state that this helps to minimise error rate as low as $1 \%$ and there is often justified in behavioural research for sample size of fewer than 30 participants and 500 . Samples greater than 30 ensures the researcher has the benefits of the central limit theorem (Abranovic, 1997). While a sample above 500 sample gives confidence that sample error will not exceed $10 \%$ of standard deviation at all times. It is better as the more data are collected and improved its statistical strength becomes in increasing the sample size. However, out of 1067 respondents administered the questionnaire on, 902 participants were duly filled and returned for the purpose of the study analysis in all the oil and gas industry in Nigeria. The implication of this is that $84.5 \%$ of the entire surveyed respondents filled the questionnaire and ensured they attended to the survey and this marks greater value of the respondents.

A probability sampling technique was used in selecting the respondents for this study, the choice of using this strategy is that it prevents subjective nature of the researcher when at the time of administering the instrument to the participants. It is a strategy of choice for an unknown function in a particular event (Grochenig et al., 2010). The justification for using probability sampling strategy is that it uses the ethos of randomization which has credence in giving every subject in the population the same opportunity of been picking in the selection. Another reason for using this technique is that it is suitable when the researcher is applying the research findings to a particular study population and research site (Hitt \& Greer, 2012). While data analytic strategy is Pearson momentum correlation, the choice of this analytic model is that it helps in establishing relationships that exist between two or more variables of interest, it shows 
the strength of the relationship between two variables. It explains a statistical model which allows the researcher to examine the association between two variables on other characteristics (Cohen et al., 2007). The justification of employing correlation for the study is to enable one value of the variable to be predicted from any known value of the other variable.

\section{PILOT STUDY}

Thirty-two items were designed to measure the degree to which employees voice drive productivity in oil companies in Nigeria. A seven-point Likert scale measure was used to evaluate the extent to which an individual employee is allowed to express himself/herself and by extension provoke productive work behaviour. The scale ranges from strongly agree to strongly disagree, A Cronbach alpha score of 0.70 shows high reliability is linked with the scale (Cronbach, 1951; Nunnally, \& Bernstein, 1994). The reliability test score in table 1 shows highreliability scores, a pilot study was conducted using 20 employees of some firms aside from main oil firms of this study. All the constructs of this study show a significant reliability test from communication and exchange of views variable which gives 0.86 , employee collective representation has 0.82 Cronbach alpha, employee engagement attracts 0.79 reliability score, upward problem solving has an alpha scale of 0.81 . While employee contribution construct has 0.76 , improved management systems reliability score of 0.80, employee supervisor-subordinate relationship has 0.72 , employee participation 0.89 employee productivity, 0.78 . Largely, it shows that the instrument is strongly reliable.

The demographic profile of respondents in Table 1 shows that the bulk of the participants were males, constituting 53.4 percent of the total surveyed respondents. Respondents who were 30 years but less than 50 years of age account for 49.9 percent of the total survey while individuals who were less than 30 years of age constitute 21.8 percent. Employees who were 50 years and above constitute a significant proportion of 28.3 percent of the entire respondents. Majority of the respondents sampled were married as they constitute 49.9 percent, while 38.8 were single. The divorced, widow and widower account for the insignificant value of 11.3 percent. On the educational background of the survey respondents, the majority of then were holders of bachelor degree as well as masters degree 44.3 percent and 22.2 percent respectively. This shows that the population were informed. Those who hold national diploma certificate were

Table 1: Construct Reliability

\begin{tabular}{clc}
\hline \multicolumn{1}{c}{ Instrument } & \multicolumn{1}{c}{ Dimension } & Reliability Score \\
\hline Employee Voice and employee productivity & Communication / Exchange of views & 0.86 \\
& Employee Collective Representation & 0.82 \\
& Employee Engagement & 0.79 \\
& Upward problem solving & 0.81 \\
& Employee Contribution & 0.76 \\
& Improved management systems & 0.80 \\
& Employee Supervisor-subordinate relationship & 0.72 \\
& Employee Participation & 0.89 \\
& Employee Productivity & 0.78 \\
\hline
\end{tabular}

Source: Survey, 2018 
20 percent, while individuals with population had 1 to 20 years work professional qualifications were 13.5 experience in oil and gas business in Nigeria, percent. Working experience of the entire while 13 percent of them had 20 years sample shows that 87 percent of the entire experience and above. Employee category,

Table 2. Respondents' Demographic Profile

\begin{tabular}{clcc}
\hline & Features & Frequency & Percent \\
\hline \multirow{2}{*}{ Sex } & Male & 482 & 53.4 \\
& Female & 420 & 46.6 \\
& Total & 902 & 100.0 \\
\hline \multirow{3}{*}{ Age (in years) } & Less than 30 & 197 & 21.8 \\
& 30 but less than 40 & 235 & 26.1 \\
& 40 but less than 50 & 215 & 23.8 \\
& 50 but less than 60 & 255 & 28.3 \\
& Total & 902 & 100.0 \\
\hline \multirow{3}{*}{ Marital status } & Single & 350 & 38.8 \\
& Married & 450 & 49.9 \\
& Divorced & 42 & 4.7 \\
& Widower & 35 & 3.9 \\
& Widow & 25 & 2.7 \\
& Total & 902 & 100.0 \\
\hline \multirow{2}{*}{ Educational Qualification } & National Diploma & 180 & 20.0 \\
& Bachelor's degree or equivalent & 400 & 44.3 \\
& Masters' degree & 200 & 22.2 \\
& Professional qualification & 122 & 13.5 \\
& Total & 902 & 100.0 \\
\hline
\end{tabular}

Source: Field Survey, 2018

Table 3. Individual Firms' Demographic

\begin{tabular}{cccc}
\hline & Features & Frequency & Percent \\
\hline & Finance and Account & 126 & 14.0 \\
& Sales and Marketing & 148 & 16.4 \\
Departments & Admin/Human Resources & 118 & 13.1 \\
& Legal & 113 & 12.5 \\
& Government Relations & 140 & 15.5 \\
& Audit & 133 & 14.7 \\
& Procurement Unit & 124 & 13.8 \\
& Total & 902 & 100 \\
& & & 19.4 \\
& $1-5$ (in years) & 175 & 21.6 \\
& 5-10 & 195 & 22.7 \\
& $10-15$ & 205 & 23.3 \\
& $15-20$ & 210 & 13.0 \\
& 20 years above & 117 & 100.0 \\
\hline \multirow{3}{*}{ Emplorking Experience (in years) } & Total & 902 & 44.3 \\
& Junior Staff & 400 & 24.8 \\
& Senior Staff & 224 & 30.8 \\
& Principal Officer & 278 & 100.0
\end{tabular}

Source: Field Survey, 2018 
44 percent of them were junior staff, 24.8 percent of them were in senior level in their various organisations, while 30.8 percent were principal officers.

\section{PRESENTATION OF RESULTS}

\subsection{Test of Hypotheses}

Eight hypotheses were postulated for the study which signified that:

1. Ho1: There is no relationship between communication/exchange of views and employee productivity.

2. Ho2: Employee collective representation has no correlation with employee productivity.

3. Ho3: Employee engagement has no positive influence on employee productivity.

4. Ho4: Upward problem solving has no significant relationship on employee productivity.

5. Ho5: There is no correlation between employee participation and employee productivity.

6. Ho6: Employee contribution in the workplace has no relevance on employee productivity.

7. Ho7: There is no relationship between improved management systems and employee productivity.

8. Ho8: There is no connection between employee Supervisor-subordinate relationship and employee productivity.

Ho1: There is no relationship between communication/exchange of views and employee productivity. In relation to the first hypothesis of the study, the result of the Pearson momentum correlation analysis as contained in Table 3 indicates that communication and exchange of views is not significantly related to employee productivity in oil companies with a negative correlation of 51.1 percent $(\mathrm{r}=51.1 \%, \mathrm{P}=$ 0.03 ) and insignificant value of 0.03 . Thus, there is no relationship between communication/exchange of views and employee productivity.

Ho2: Employee collective representation has no correlation with employee productivity. The result of the analysis depicts that there is a weak correlation

Table 4. Correlations Matrix Analysis of Drivers of Employee Voice

\begin{tabular}{|c|c|c|c|c|c|c|c|c|c|}
\hline Variables & CEV & ECR & EE & UPS & EC & IMS & ESSR & Em Part & $\mathbf{E P}$ \\
\hline $\begin{array}{l}\text { Communication and Exchange of Views } \\
\text { (CEV) }\end{array}$ & 1 & & & & & & & & \\
\hline $\begin{array}{l}\text { Employee Collective Representation } \\
\text { (ECR) }\end{array}$ & $\begin{array}{l}.934 * * \\
(0.00)\end{array}$ & 1 & & & & & & & \\
\hline Employee Engagement (EE) & $\begin{array}{l}.896 * * \\
(0.00)\end{array}$ & $\begin{array}{l}.873 * * \\
(0.00)\end{array}$ & 1 & & & & & & \\
\hline Upward Problem Solving (UPS) & $\begin{array}{l}.955^{* *} \\
(0.00)\end{array}$ & $\begin{array}{l}.967 * * \\
(0.00)\end{array}$ & $\begin{array}{l}.876^{* *} \\
(0.00)\end{array}$ & 1 & & & & & \\
\hline Employee Contribution (EC) & $\begin{array}{c}.942 \\
(0.00)\end{array}$ & $\begin{array}{l}.912^{* *} \\
(0.00)\end{array}$ & $\begin{array}{c}.946 \\
(0.00)\end{array}$ & $\begin{array}{c}.920 \\
(0.00)\end{array}$ & 1 & & & & \\
\hline Improved Management System (IMS) & $\begin{array}{c}.937 \\
(0.000)\end{array}$ & $\begin{array}{l}.942^{* *} \\
(0.036)\end{array}$ & $\begin{array}{l}.910 * * \\
(0.000)\end{array}$ & $\begin{array}{c}.934 \\
(0.00)\end{array}$ & $\begin{array}{l}.947 * * \\
(0.00)\end{array}$ & 1 & & & \\
\hline $\begin{array}{c}\text { Employee Supervisor-subordinate } \\
\text { Relationship (ESSR) }\end{array}$ & $\begin{array}{c}.865 \\
(0.000)\end{array}$ & $\begin{array}{l}.820 * * \\
(0.00)\end{array}$ & $\begin{array}{l}.956^{* *} \\
(0.013)\end{array}$ & $\begin{array}{l}.849 * * \\
(0.00)\end{array}$ & $\begin{array}{l}.922 * * \\
(0.00)\end{array}$ & $\begin{array}{c}.876 \\
(0.00)\end{array}$ & 1 & & \\
\hline Employee Participation (EmParti) & $\begin{array}{c}.975 \\
(0.000)\end{array}$ & $\begin{array}{l}.922^{* *} \\
(0.00)\end{array}$ & $\begin{array}{l}.921^{* *} \\
(0.00)\end{array}$ & $\begin{array}{l}.940 * * \\
(0.00)\end{array}$ & $\begin{array}{l}.955^{* *} \\
(0.00)\end{array}$ & $\begin{array}{l}.953 * * \\
(0.00)\end{array}$ & $\begin{array}{l}.898^{* * *} \\
(0.00)\end{array}$ & 1 & \\
\hline Employee Productivity (EP) & $\begin{array}{c}-.511^{* *} \\
(0.03)\end{array}$ & $\begin{array}{l}.237 * * \\
(0.02)\end{array}$ & $\begin{array}{l}.450^{* *} \\
(0.02)\end{array}$ & $\begin{array}{l}.591^{* *} * \\
(0.00)\end{array}$ & $\begin{array}{l}.484^{* *} \\
(0.00)\end{array}$ & $\begin{array}{l}.569^{* * *} \\
(0.00)\end{array}$ & $\begin{array}{l}.398 * * \\
(0.00)\end{array}$ & $\begin{array}{l}.506^{* * *} \\
(0.00)\end{array}$ & 1 \\
\hline
\end{tabular}

**Correlation is significant at the 0.01 level $(2$-tailed $) \mathrm{n}=902$ 
between employee collective representation and employee productivity exist at 23.7 percent $(\mathrm{r}=0.237, \mathrm{P}=0.02)$ given the alpha value of $2 \%$ it shows that no significant correlation between the two postulated variables. Thus, it employee collective representation has no significant correlation with employee productivity.

Ho3: Employee engagement has no positive influence on employee productivity. On hypothesis three of the study, the Pearson product-moment correlation coefficient shows another weak strength between employee engagement and employee productivity at $45 \%(\mathrm{r}=0.450, \mathrm{P}=0.02)$. The correlation coefficient shows a measure of the strength and direction that exist between employee engagement and productivity at the weak association of 45 percent, while a non-significant relationship exists between the two variable given the alpha value of $2 \%$. However, the correlation rule is said to be significant at the 0.01 level while the $P$ value is 0.02 . Hence, employee engagement has no positive influence on employee productivity.

Ho4: Upward problem solving has no significant relationship with employee productivity. The result of the Pearson correlation on the fourth hypothesis shows a significant one. It indicates that 59.1\% $(\mathrm{r}=0.591, \mathrm{P}<0.01)$ strength of relationship exists between upward problem solving and employee productivity in the organisations. Given the P value from the analysis at 0.00 , it shows a significant value and association between the two variables. Hence, Upward problem solving has significant relationship employee productivity.

Ho5: There is no correlation between employee participation and employee productivity. The fifth hypothesis of the study, from Table 3, the intercept between opinion relating to employee participation and employee productivity show a significant relationship but weak. This implies that though the association between the two perceptions is weak at $48.8 \%$, it is significant $(\mathrm{r}=0.488, \mathrm{P}<0.01)$. It is suggested that allowing the employee to participate in the affairs of the organisation enhance their productivity. Hence, the alternative hypothesis is accepted that there is correlation between employee participation and employee productivity.

Ho6: Employee contribution in the workplace has no relevance on employee productivity hypothesis was tested using correlations coefficients test. Pearson product moment correlations coefficient of (0.569) at $56.9 \%$ indicates that employee contribution and employee productivity are moderately significant and positively associated with each other at 0.00 level of significance as contained in Table 3. Hence, the null hypothesis of employee contribution in the workplace has no relevance on employee productivity is rejected. Thus, employee contribution has relevance to employee productivity.

Ho7: There is no relationship between improved management systems and employee productivity. The result is the correlation coefficient on the two perceptions above in Table 3 indicates a very weak association between improved management systems and employee productivity at $39.8 \%(\mathrm{r}=0.398, \mathrm{P}<0.01)$. It shows that improved management systems are connected with enhanced employee productivity at a symbolic weak strength of the relationship. Hence, the null hypothesis that states that there is no relationship between improved management systems and employee productivity is rejected and accept the alternative hypothesis that there is a relationship between improved management 
systems and employee productivity.

Ho8: There is no connection between employee supervisor-subordinate relationship and employee productivity. Given the result of the correlation from Table 3 , a significant outcome emerges with correlation coefficient value of $50.6 \%$ (0.506, $\mathrm{P}<0.01)$, which shows moderate or average correlation exist between employee supervisor-subordinate interaction and employee productivity. Hence, the null hypothesis is rejected and the alternative hypothesis is accepted there is no connection between employee Supervisor-subordinate relationship and employee productivity.

\section{DISCUSSION OF FINDINGS}

This study has shown a significant outcome on all the eighth propositions in relation to employee work productive behaviour in Nigeria oil and gas industry.

The hypothesis Hol demonstrated an inverse relationship between communication/exchange of views and employee productivity in Nigeria oil firms. The implication of this is that management of the organisations never encourages twoway communication and exchange of ideas in the business environment and by extension its negative influence on the productive work behaviour of oil and gas workforce in Nigeria. It implies that all the oil and gas organisations never initiate effective communication and exchange of views that will foster cultural norms which instil a conversational sensibility throughout their firms. It appears that most of the firms fail to listen to views of their workforce which have an overbearing influence on the productivity of the entire workforce, qualities -operational flexibility, high level of employee engagement, a tight strategic alignment that will give them a competitive edge. Practically, the finding indicates that employees are not allowed to be heard nor express themselves with the management especially when it comes to issues bothering employee welfare or motivation. This finding takes a similar position with the meta-analysis study of Constantin and Baias (2015) whose finding shows that internal communication and exchange of ideas were underestimated by the management of organisations and this largely affect employee commitment to work and level of employee engagement.

Hypothesis Ho2 of the study also have a similar interpretation; employee collective representation has no correlation with employee productivity. It is obvious that no functional voice in place in all the oil firms in Nigeria. Apparently, the industry did not allow unionism or labour representation so that the union will not disrupt their selfserving policies. It shows a weak correlation between collective representation and productive work behaviour of the entire workforce. The study demonstrated that management did not stimulate the idea of employee collective representation rather they encourage individual representation or divide and rule approach. It is obvious that this has negative on the performance of the employees and bothers around the entire organisational performance. This speaks volume on the nature of work of some of the employees in the oil and gas in which some attest to the fact that they are casual workers. Some of the oil firms appreciate using graduates for casualization in order to cut down on expenses and gain more at the detriment of the workforce. This finding corroborates the study of Purcell and Hall (2014) whose finding shows a gap in 
workers' representation in cross-country study conducted.

Hypothesis $\mathrm{Ho} 3$ of this study indicates that employee engagement has no positive influence on employee productivity. This is evidence in the motivational strategies of the oil and gas companies in Nigeria. The degree of how workers are absorbed with the work and ability to go the extra mile in achieving the goals of the organisations are decreasing by extension it speaks on the quality of the productivity of the workforce. Employee engagement is considered a psychological state in conjunction with its behavioural expression. It is glaring when workers are not allowed to express their opinions and feeling regarding challenges in the workplace low absenteeism, higher employee retention, low employee effort, decreased productivity, reduced quality and error rates, low profitability amongst others are the consequences of not allowing employee engagement practice in Oil and gas firms in Nigeria. This finding takes a symmetrical position with the study of Ncube and Jerie (2012) whose study employed Gallup questionnaire to the nonmanagerial workforce to assess their degree of engagement whilst interviews were conducted with managerial employees. Their findings depict that majority of nonmanagerial employees were disengaged, few of them were not engaged. While managerial employees, three were highly disengaged, a whole lot of them were not engaged and only a minority of them were engaged.

Hypothesis Ho4 shows that upward problem solving has a significant relationship with employee productivity. A Large pool of the workforce attest to the fact that they were given opportunity in providing feedback on certain issues but not all matters, is not so much as discourse but more as a means of offering ideas to improve the performance of employees. Virtually, all the firm's employed downward communication pattern in one way or the other, ninety percent of the entire surveyed organisations have electronic media means of communication which forge the ease at which their workforce could respond to management or express their opinions to management. This outcome finds similar expression in the study of Alfayad and Arif (2017) whose study also reveals that communications, upward problem-solving practice is considered as a unique and crucial element in improving job satisfaction levels and emboldens employee to involved in their organisational vision implementation.

Hypothesis Ho5 reveals that there is a correlation between employee participation and employee productivity. This shows an essential influence of employee participation as participatory management of employee in decision making processes forge a good sense of employee ownership in the workplace. The industry appreciates the fact that participation of employee is key to the success of the organisations. The outcome of this finding is consistent with the result of Kuye and Sulaimon (2011) whose study investigate the employee participation and involvement in decision making and firms' performance in the manufacturing sector of Nigeria. Also, the study of Creigh et al. (2012) and Bradley and Nejad (2012) find similar expression with this study. Their study found that employee participation is very critical in the overall performance of firms by means of allowing them to freely express their opinion and intentions at all levels.

Hypothesis Ho6 shows the significant relevance of employee contribution in the workplace on employee productivity. 
Employee contribution in the organisation does not only enhance efficiency, growth and innovation but also foster employee trust in the organisation. It shows that a sign of appreciation for their contribution, their enhanced enthusiasm and commitment always lead to better productivity and loyalty. This finding is consistent with the study of Dobre (2013) in employee motivation and performance, whose study indicates that appreciation of employee contributions enhances the performance of the organisation.

Another outcome of this study from Hypothesis $\mathrm{Ho} 7$ shows a significant result that there is a positive relationship between improved management systems and employee productivity. In addition to improvements evolving from employee contributions, there were also derivatives that were believed to improve people management systems and processes. It was established from this study that the greater willingness by the oil and gas workforce to challenge issues and decisions in the workplace had an educative impact for management by enhancing human capital systems and by extension productivity of the workforce. This finding is consistent with the result of Grayson, Nyamana and FunjikaMulenga (2016) whose outcome discovered the positive connection between quality management practices, productivity and profitability in the manufacturing industry in Zambia.

The last finding of this study regarding Hypothesis $\mathrm{Ho} 8$ on employee voice in oil industry indicates that there is an association between employee supervisor-subordinate relationship and employee productivity. It demonstrates a better and improved employee supervisor-subordinate relationship, always influence employee productive work behaviour in the workplace. The outcome of the study signifies that there exist quality social interactions and networks between workforce and management of each organisation which influence the ability to embark on tasks and solve daily challenges at work. It further demonstrates that there exists critical teamwork in the workforce which ensures high productivity in the organisations. This result finds symmetrical stance with the study of Lee (2001) whose outcome indicates that the quality of superior-subordinate relationship is key to employees and corporate organisation as employees recognise their immediate superior as the most preferred point of information regarding any event or incident in the firm, moreover, employees recognise their immediate superior as the main source for receiving information from the management at the top.

\section{CONCLUSION RECOMMENDATIONS}

This study has established a mixed result on speaking up in organisations in Nigeria, it has revealed that employee voice is considered as a unique and crucial element in improving employee work behaviour. However, the oil and gas industry had a poor communication system with their workforce. Although, there seems to be enhanced technology and media communication system in which all the firms use to pass information across to the workforce in the workplace, yet it is a poor pattern, given the result of this study. It is demonstrated that Nigeria oil and gas system as the majority of the oil companies in Nigeria had their owners from America and the United Kingdom in which the management frown at 
trade unionism or collective representation in their various countries in which the principles have been passed on to any country or national boundary of their operations. If not for Nigerian National Petroleum Corporation (NNPC) regulation for trade unionism majority of them would not have joined Nigeria Union of Petroleum and Natural Gas Workers (NUPENG), and Petroleum and Natural Gas Senior Staff Association of Nigeria (PENGASSAN). This is pervasive in employee engagement and fully committed to the work environment. It shows that most of them did not deeply absorb themselves with the work as graduates were using for casualization in the oil companies in Nigeria. On the other hands, the study demonstrates a positive outcome regarding upward problem solving, employee participation and employee productivity, employee contribution, improved management systems and employee supervisor-subordinate relationship. To be more competitive in the global market, management of oil and gas firms needs motivate their workforce, allow them to freely express themselves regarding challenges and issues bothering the workplace as this will gear them towards involving in the organisational vision implementation. Therefore, the following are suggestions and recommendations made by the author from the outcome of the study in improving Nigeria oil and gas corporate industry as firms should seek to:

a. Building a constructive and productive climate which stimulates employees' ideas and opinions that contribute to the success and growth of the organisations.

b. Motivating workforce by encouraging their interests and inspiring the workforce to think differently and involve them in organisational problems and opportunities and allowing dynamic workplace where employee voice will be appreciated and accepted.

c. Management especially decision makers must cultivate and create strategies and schemes like joint consultation and structured feedback with the intention of stimulating employee voice behaviour.

d. Internal communication should be encouraged in all the organisations, only an effective internal communication can help build employee commitment and trust in management. Internal communication will offer employees opportunities to feed their views to the concerned authority.

e. Management should at all times trust their workforce and practice effective management by objective and employee participatory/involvement management which will motivate their workforce to have optimal performance at work.

f. Management of oil and gas industry should also be sensitive and responsive to the employee body language as this will improve productivity, hence policy interventions which will change beliefs and attitudes of managers and employees of the organisations towards one another should be encouraged, this will afford managers to be responsive to employee voice in the organisation.

g. Relationships amongst boss and employees needed to be strengthened in order to accomplish outstanding organisational goals and objectives.

iv. Management should seek from time to time what is/are the issues with their workers with this, employees will communicate their opinion and minds and this will afford them to have a sense of recognition in the workplace. 


\title{
ГЛАС ЗАПОСЛЕНИХ: ОТВОРЕНИ РАЗГОВОР У ОРГАНИЗАЦИЈИ И КОРЕЛАЦИЈА СА ПРОДУКТИВНШТУ У НАФТОЈ И ГАСНОЈ ИНДУСТРИЈИ - ЕМПИРИЈСКО ИСТРАЖИВАНЈЕ ИЗ НИГЕРИЈЕ
}

\author{
Olusegun Emmanuel Akinwale
}

Извод

Разумевање и тумачење гласа запослених критички је привлачило пажњу истраживача и практичара у последњих неколико година. Компаније верују у радну снагу, да запослени могу отворено да изразе своје лично мишљење и забринутост за већу надлежност у организацији. Такође, верује се да они могу утицати на одлуке својим оптимистичким ставом и конструктивним понашањем. За потребе ове студије је анкетирано 1067 запослених у нигеријској индустрији нафте и гаса, од чега је примљено 902 одговора и коришћено за истраживање. Подаци су добијени од учесника користећи упитник од 19 питања помоћу методологије за узорковање вероватноће, док је само истраживање било дизајнирано као унакрсно. Налази овог истраживања указују на кохерентност и доследаност са литературом. У истраживању је коришћено осам димензија као покретач гласа запослених у Нигеријској нафтној и гасној индустрији, што је дало мешовите исходе. Један од покретача је комуникација / размена мишљења која је била у инверзној вези са продуктивношћу запослених. Колективно представљање запослених као и њихово ангаживање, такође су забележели незнатнтну повезаност са продуктивним понашањем запослених. Међутим, укључивање запослених, побољшани системи управљања, супервизорски-подређени однос, допринос радне снаге у решавање проблема су значајно у корелацији са елементиме производног понашања запослених. Студија је користила описну статистику и Пирсонов корелациони моменат у анализирању података прикупљених од учесника и закључила да радна снага у нигеријскеој индустрији нафте и гаса није чврсто ангажоване у радном окружењу, због уоченог изазова да им се не дозволи да буду прописно заступљени и да их обесхрабри размена њихових ставова и идеја.

Кључне речи: глас запослених, учешће запослених, побољшани системи управљања, надзорад запосленима - подређени однос, двосмерна комуникација, продуктивност запослених

\section{References}

Abranovic, W.A. (1997). Statistical thinking and data analysis for managers. Reading, MA, USA: Addison-Wesley Publishing Company.

Alfayad, Z., \& Arif, L.S.M. (2017). Employee voice and job satisfaction: An application of Herzberg's two-factor theory. International Review of Management and Marketing, 7 (1), 150-156.
Anyago, C., Ojera, P., Ochieng, I. (2015). Meaning and application of employee voice. International Journal of Scientific Research and Innovative Technology, 2 (5), 10-16.

Avery, D.R., Richeson, J.A., Hebi, M., \& Ambady, N. (2009). It doesn't have to be uncomfortable: The role of behavioural scripts in interracial interactions. Journal of Applied Psychology, 94, 1382- 1393.

Ballone, C. (2007). Consulting your clients to leverage the multi-generational 
workforce. Journal of Practical Consulting, 2, 9-15.

Batt, R., Colvin, A., \& Keefe, J. (2002). Employee voice, human resource practices, and quit rates: Evidence from the telecommunications industry. Industrial and Labour Relations Review, 55 (4), 573-594.

Beirne, M. (2015). Idealism and the applied relevance of research on employee participation. Work, Employment \& Society, 22 (4), 675-693.

Beulah, E., \& Obot, D. (2013). Perceived effects of gas flaring on socio-economic well-being of farming household in Ogbia local government area, Bayelsa State. American Journal of Research Communication, 1 (3), 27-34.

Bornstein, T. (2007). Quality improvement and performance improvement: Different means to the same end? International Society for Performance Improvement, QA Brief, 6-12.

Bourdieu, P. (1980). Social capital. Proceedings of the Research in Social Sciences, 31, 2-3.

Boxall, P., \& Purcell, J. (2011). Strategy and human resource management, 3rd edn. Basingstoke, UK: Palgrave Macmillan.

Bradley, K., \& Nejad, A. (2012). Managing owners: The national freight company buy-out in perspective.: Cambridge University Press.

Budd, J.W., Gollan, P.J., \& Wilkinson, A. (2010). New approaches to employee voice and participation in organisations. Human Relations, 63 (3), 303-310.

Burris, E.R. (2012). The risk and rewards of speaking up: Managerial responses to employee voice. Academy of Management Journal, 55 (4), 851-875.

Campione, W.A. (2014). The influence of supervisor race, gender, age, and cohort on millennials' job satisfaction. Journal of
Business Diversity, 14(1), 18-34.

Chalikias, M., Kyriakopoulos, G., Skordoulis, M., \& Koniordos, M. (2014). Knowledge management for business processes: employees' recruitment and human resources' selection Cambridge, UK: a combined literature review and a case study. In: communications in computer and information science. Knowledge-based software engineering, Proceedings of 11th Joint Conference on Knowledge-Based Software Engineering - JCKBSE, Eds., Kravets et al. Volgograd, September 2014. Switzerland: Springer International Publishing, pp. 505-520.

Chen, Y.R., Chen, X., \& Portnoy, R. (2009). To whom do positive norm and negative norm of reciprocity apply? Effects of inequitable offer, relationship, and relational-self orientation. Journal of Experimental Social Psychology, 45 (1), 24-34.

Cohen, D., \& Prusak, L. (2001). In good company: How social capital makes organisations work. MA, USA: Harvard Business School Press

Cohen, L., Manion, L. \& Morrison, K. (2007). Research methods in education, 6th edn. New York, USA: NY, Routledge.

Constantin, E.C., \& Baias, C.C. (2015). Employee voice - Key factor in internal communication. Procedia - Social and Behavioural Sciences, 191, 975-978.

Creigh, S., Donaldson, N., \& Hawthorn, E. (2012). A stake in the firm. Employment Gazette, 229-236.

Cronbach, L.J. (1951). Coeffiecient alpha and the interval structure of tests. Psychometrika, 16, 297-334.

Detert, J.R., \& Edmondson, A.C. (2011). Implicit voice theories: Taken-for-granted rules of self-censorship at work. Academy of Management Journal, 54 (3), 461-488. 
Dobre, O.I. (2013). Employee motivation and organizational performance. Review of Applied Socio-Economic Research, 5 (1), 53-64.

Dwomoh, G. (2012). The relationship between employee voice and organisational performance at electricity company of Ghana. European Journal of Business and Management, 4 (6), 1-6.

Farndale, E., Van Ruiten, J., Kelliher, C., \& Hope-Hailey, V. (2011). The influence of perceived employee voice on organisational commitment: An exchange perspective. Human Resource Management, 50 (1), 113129.

Ferragina, E. (2010) Social Capital and Equality: Tocqueville's legacy. The Tocqueville Review, 31, 73-98.

Freeman, R.B., Boxall, P., \& Haynes, P. (2007). What workers say: Employee voice in the Anglo-America World. Ithaca, NY, USA: Cornell University Press

Gilley, A., Gilley, J.W., \& McMillan, H.S. (2012). Organizational Change: Motivation, Communication, and Leadership Effectiveness. Performance improvement quarterly, 21 (4), 75-94.

Goldberg, C.B., Clark, M.A., \& Henley, A. B. (2011). Speaking up: A conceptual model of voice responses following the unfair treatment of others in non-union settings. Human Resource Management, 50 (1), 75-94.

Gorden, W. I. (1998). Range of employee voice. Employee Journal Responsibility \& Rights, 1 (4), 283-299.

Grayson, K., Nyamana, M., \& FunjikaMulenga, P. (2016). Management quality, productivity and profitability in Zambia. The International Growth Centre (IGC), Working Paper, F-41303-ZMB, 1-51.

Griffin, R., \& Moorhead, G. (2013). Organizational behaviour: Managing people and organizations. New York, USA: Cengage Learning

Grochenig, K., Potschery, B.M., \& Rauhutz, H. (2010). Learning trigonometric polynomials from random samples and exponential inequalities for Eigenvalues of random, available at http://www.rauhurt.ins.un-bonn.de, retrieved on $4 / 10 / 2017$.

Hambley, L.A., O’Neill, T.A., \& Kline, J.T.A. (2014). Virtual team leadership: the effects of leadership styles and communication medium on team interaction styles and outcomes. Organizational Behaviour and Human Decision Processes, 103, 1-20.

Hirschman, A.O. (1970). Exit, voice, and loyalty: Response to decline in firms, organisations, and states. Cambridge, UK: Harvard University Press

Hitt, P., \& Greer, C.R. (2012). The value of research and its evaluation in business schools: Killing the goose that laid the golden egg? Journal of Management Inquiry, 21 (2), 236-240.

Holland, P., Pyman, A., Cooper, B. K., \& Teicher, J. (2011). Employee voice and job satisfaction in Australia: The centrality if direct voice. Human Resource Management, 50 (1), 95-111.

Hussein, S., Moriarty, J., Stevens, M., Sharpe, E., \& Manthorpe, J. (2013). Organisational factors, job satisfaction and intention to leave among newly qualified social workers in England. Social Work Education, 33 (3), 381-396.

Jablin, F.M. (2009). Superior-subordinate communication: The state of the art. Psychological Bulletin, 86 (9), 1201-1222.

Kessels, J.W., Poell, R.F. (2004). Andragogy and social capital theory: Theory implications for human development. Advances in Developing Human Resources, 
10 (10), 1-12.

Kim, J., MacDuffie, J.P., \& Pil, F.K, (2010). Employee voice and organisational performance: Team versus representative influence. Human Relations, 63 (3), 371-394.

Kuye, O.L., \& Sulaimon, A.A. (2011). Employee involvement in decision-making and firms performance in the manufacturing sector in Nigeria. Serbian Journal of Management, 6 (1), 1-15.

Lee, J. (2001). Leader-member exchange, perceived organizational justice, and cooperative communication. Management Communication Quarterly, 14 (4), 574-589.

Lin, N. (2001). Social capital: A theory of social structure and action. Cambridge, UK: Cambridge University Press.

Macleod, D., \& Clarke, N. (2009). Engage for success: Enhancing performance through employee engagement. A report to government. London, Department for Business, Innovation and Skills (BIS)

Mayfield, M., \& Mayfield, J. (2009). The role of leader-follower relationships in leader communication: The test using the LMX and motivating language models. Journal of Business Inquiry, 8 (1), 65-82.

Morrison, E.W. (2011). Employee voice behaviour: Integration and directions for future research. The Academy of Management Annals, 5 (1), 373-412.

Morrison, E.W., Wheeler-Smith, S.L., \& Kamdar, D. (2011). Speaking up in groups: A cross-level study of group voice climate and voice. Journal of Applied Psychology, 96 (1), 183-191.

Ncube, F., \& Jerie, S. (2012). Leveraging employee engagement for competitive advantage in the hospitality industry. A comparative study of hotels $\mathrm{A}$ and $\mathrm{B}$ in Zimbabwe. Journal of Emerging Trends in Economics and Management Sciences, 3 (4), 380-388.
Nunnaly, J.C., \& Bernstein, I.H. (1994). Psychometric theory (3rd edn). New York, USA: McGraw-Hill.

Nwanyanwu, D.H., Fred-Nwagwu, F.W., \& Yousuo, A. (2015). Oil and gas multinational companies' activities in Nigeria: The challenges in methods of waste management in Niger Delta. IOSR Journal of Environmental Science, Toxicology and Food Technology (IOSR-JESTFT), 9 (9), 109-117.

Ohiorenoya, J.O., \& Uwadiae, O.S. (2016). Contract staffing and employee engagement in oil and gas industry in Nigeria. (A study of Shell Petroleum Development Company), West Nigeria. International Journal of Business and Social Sciences, 7 (10), 196-206.

Okpu, T., \& Jaja, S.A. (2014). Joint consultation and workers' commitment in Nigeria banking industry. International Journal of Business and Management, 9 (3), 53-63.

Oloo, P.A., \& Orwar, B.H. (2016). Influence of participatory decision-making of junior staff at the retail markets in Kenya. An empirical study of Uchumi supermarket in Nairobi. International Journal of Education and Research, 4 (2), 1-18.

Oyejide, T., \& Adewuyi, A. (2011). Enhancing linkages of oil and gas industry in the Nigeria economy, 8th edn. Ibadan, 32-33.

Preuss, G., \& Lautsch, B. (2002). The effect of formal versus informal job security on employee involvement programmes. Relations Industrielles, 57 (3), 517-539.

Purcell, J. (2014). Can employee voice and participation unlock employee engagement? Insights Melbourne Business and Economics, 15 (1), 23-30.

Rees, C., Alfes. K., \& Gatenby, M. (2013). Employee voice and engagement: Connections and consequences. International 
Journal of Human Resource Management, 24 (14), 2780-2798.

Salvendy, G. (2012). Handbook of human factors and ergonomics. Hoboken, NJ, USA: Wiley.

Sedgwick, P. (2014) Cross-sectional studies: Advantages and disadvantages. BMJ, 348-349.

Seibert, S.E., Kraimer, M.L., \& Liden, R.C. (2001). A social capital theory of career success. Academy of Management Journal, 44 (2), 219-237.

Umar, M., \& Hassan, Z. (2013). Antecedents and outcomes of voice and silence behaviours of employees of tertiary educational institutions in Nigeria. ProcediaSocial and Behaviour Sciences, 97, 188-193.

Van Buren, H., \& Greenwood, M. (2008). Enhancing employee voice: Are voluntary employer-employee partnerships enough? Journal of Business Ethics, 81 (1), 209-221.

Weisberg, H.F., \& Bowen, B.D. (1977). An introduction to survey research and data analysis. San Francisco, California, USA : W.H. Freeman.

Williamson, M.G. (2008). The effects expanding employee decision making on contributions to firm value in an informal reward environment. Contemporary Accounting Research, 25 (4), 1184-1209.

Yin, L.W. (2013). Inclusive leadership and employee voice: Mediating roles of psychological safety and leader-member exchange. Doctoral Thesis, Hong Kong: Hong Kong Baptist University.

Zhang, Z., \& Xiuyuan, G.A.O. (2014). The impact of transformation leadership on employee voice behaviour: The role of organizational identification and procedural. International Business and Management, 9 (2), 168-172. 